\title{
Bridelia ferruginea Benth leaves attenuates diabetes nephropathy in STZ-induced rats via targeting NGAL/KIM-1/cystatin c gene
}

\author{
Damilola Alex Omoboyowa $^{1 *}$ (D) Kayode Olayele Karigidi ${ }^{2}$ and Temitope Cosmas Aribigbola ${ }^{3}$
}

\begin{abstract}
Background: Renal failure is among the main complications of diabetes disorders and free radical from hyperglycemia is the major cause of this nephrotic complication. This study investigated the therapeutic effects of Bridelia ferruginea Benth on nephrotic damage in streptozotocin (STZ) induced diabetic rats. Diabetes mellitus was induced by injection of $50 \mathrm{mg} / \mathrm{kg} \mathrm{b}$. w. of STZ (intraperitoneal) in rats fasted overnight. Effect on nephropathy was assessed using biochemical, histological indices and gene expression of kidney tissue.

Results: The total flavonoids and phenolic content of petroleum ether fraction of $B$. ferruginea (PEFBF) was observed to be higher compared to diethyl ether fraction of $B$. ferruginea (DEFBF). The 1,1-diphenyl-2-picryl-hydrazyl scavenging activity of the fractions were significantly $(P<0.05)$ reduced across the concentrations compared to the standard (gallic acid). The STZinduced diabetic animals treated with 100 and $200 \mathrm{mg} / \mathrm{kg}$ b.w. of PEFBF and DEFBF showed significant $(P<0.05)$ reduction in blood glucose level on days 7, 11 and 14 compared to untreated diabetic rats. STZ-induced diabetic rats significantly $(P<0.05)$ exhibited increase plasma urea, creatinine, protein and albumin level while treatment with both fractions of $B$. ferruginea reduced the level of these parameters in treated diabetic rats. $B$. ferruginea also caused down-regulation of neutrophil gelatinase-associated lipocalin, kidney injury molecule-1 and cystatin c genes.
\end{abstract}

Conclusion: These results revealed that, the plant has hypoglycemic activity therefore provides a pharmacological basis for its folkloric use in the management of hyperglycemia and its associated renal dysfunction.

Keywords: Diabetes, Diabetic nephropathy, Gene expression, Anti-oxidant

\section{Introduction}

Diabetes mellitus (DM) is among the endocrinemetabolic disorders leading to morbidity and mortality due to its diverse complications such as retinopathy, neuropathy, and peripheral vascular disease [1]. One of the macro vascular complications of diabetes is nephropathy which is the malfunctioning of the renal system as a result of hyperglycemia. It is the major common cause of end-stage kidney dysfunction and major indication for kidney dialysis and transplantation [2]. Hyperglycemiainduced oxidative stress in diabetes is a major cause for

\footnotetext{
* Correspondence: damlexb@yahoo.com

'Department of Biochemistry, Adekunle Ajasin University, Akungba-Akoko,

Ondo State, Nigeria

Full list of author information is available at the end of the article
}

the development of diabetic complication such as diabetes nephropathy [3]. This pathway is mainly activated by sustained hyperglycemia which causes the intra-renal haemodynamic's changes through glycosylation of intrarenal proteins that induce hyperfiltration and glomerular dysfunction [4]. Chemotherapy remains the kernel of diabetes management, but most individuals with chronic diabetes condition in developing countries rely on phytotherapy which involve traditional medicines alone or synergistically with orthodox drugs.

B. ferruginea Benth a non-laticiferous scaly shrub grows to about $4 \mathrm{~m}$ high, the tree bears spines and the leaves may be small sized. The plant is pinnately veined with entire margin and an acuminate or acute apex [5]. Various phyto-constituents have been studied in $B$.

\section{Springer Open}

(c) The Author(s). 2020 Open Access This article is licensed under a Creative Commons Attribution 4.0 International License, which permits use, sharing, adaptation, distribution and reproduction in any medium or format, as long as you give appropriate credit to the original author(s) and the source, provide a link to the Creative Commons licence, and indicate if changes were made. The images or other third party material in this article are included in the article's Creative Commons licence, unless indicated otherwise in a credit line to the material. If material is not included in the article's Creative Commons licence and your intended use is not permitted by statutory regulation or exceeds the permitted use, you will need to obtain permission directly from the copyright holder. To view a copy of this licence, visit http://creativecommons.org/licenses/by/4.0/. 
ferruginea including the isolation of lignans from its roots [5]. Flavonoids such as quercetin, quercetrin, rutin, myricitrin, ferrugin and biflavonol have been reported in the bark of $B$. ferruginea [6] while rutin and quercetin have been found its leaves [5]. Crude extract from the root of $B$. ferruginea Benth has been reported to inhibit E. coli, S. aureus, S. typhi, P. mirabilis, and C. albicans growth at varying concentration of 40, 100, 60, 60 and $80 \mathrm{mg} / \mathrm{ml}$ respectively [7]. Hypoglycemic activity of coarsely powdered leaf of $B$. ferruginea Benth has been reported in clinical study by Thomford et al. [1]. Thomford et al. [8] also re-evaluate the activity of aqueous extract of $B$. ferruginea Benth leaf and its synergistic administration with metformin in the management of DM. The possible association between ether fractions of B. ferruginea leaves and diabetes complication has not been studied. Thus, this study investigated the therapeutic efficacy of petroleum and diethyl ether fractions of $B$. ferruginea Benth leaves on hyperglycemic and kidney function status of STZ treated rats.

\section{Materials and methods Reagents and chemicals}

Reagents used for the study were analytically graded. STZ was obtained from Sigma-Aldrich (USA).Urea, creatinine, protein and albumin assay kits were obtained from Randox laboratory (UK); TRIzol reagent for RNA isolation was supplied by Zymo research(USA); prime script RT reagent kits were obtained from Biolabs, UK while primers were purchased from InqabaBiotec (Hatfeild, SA). Reagents forHistological examination and stains were obtained from Sigma-Aldrich (USA). All other chemicals were purchased from a registered supplier.

\section{Animals}

Male Wistar rats (132-187 g) used for this research were purchased from the animal facilities of Biochemistry Department, Ladoke Akintola University of Technology, Ogbomoso. The rats were maintained under standard environmental conditions and fed on standard rat pellets (Ladokun feeds, Ibadan, Nigeria) and water ad libitum. The animals were acclimatized in the laboratory for fourteen days prior to the commencement of the experimental procedure. The rats were cared for according to the National Institute of Health's Guide for the Care and Use of Laboratory Animals [9].

\section{Plant}

Leaves of $B$. ferruginea Benth were collected from the medicinal plant garden, Ondo State University of Science and Technology, Okitipupa (OSUSTECH), Nigeria. Identification and authentication were done by botanist at the Department of Biological Sciences, OSUSTECH and a voucher specimen number (OSUSTECH/025) was assigned after depositing the plant at OSUSTECH Herbarium.

\section{Preparation of fractions}

The powdered leaves material $(100 \mathrm{~g})$ was heated in 500 $\mathrm{ml} \mathrm{HCl}(2 \mathrm{M})$ for $30 \mathrm{mins}$ in boiling water bath. The extract $(300 \mathrm{ml})$ was cooled, filtered and divided into two equal portions. One portion $(150 \mathrm{ml})$ was extracted with petroleum ether. The other portion $(150 \mathrm{ml})$ was extracted with diethyl ether to obtain the phenolic compounds in both fractions [10]. The fractions were filtered using whatman filter paper and concentrate in vacuum with the aid of a rotary evaporator (Bibby Sterilin, UK). The extract yields were $10.2 \mathrm{~g}$ of petroleum ether fraction which constituted $1.27 \%$ of the total weight of powdered sample used and $8.5 \mathrm{~g}$ of diethylether fraction which constituted $1.06 \%$ of the total weight of powdered sample used.

\section{In-vitro antioxidant analysis of fractions}

Total phenolic content determination The total phenolic contents of the fractions were estimated according to the Folin-Ciocalteau colorimetric procedure described by Ainsworth and Gillespie [11] using gallic acid as standard. Briefly, $0.2 \mathrm{ml}$ of fraction was added to $1 \mathrm{ml}$ of Folin-Ciocalteau phenol reagent. After $4 \mathrm{~min}, 0.8 \mathrm{ml}$ of $7.5 \% \mathrm{Na}_{2} \mathrm{CO}_{3}$ solution was added and the solution was allowed to stand for $2 \mathrm{~h}$. Absorbance was read at 765 $\mathrm{nm}$. The same protocol was repeated with standard garlic acid at $10-200 \mu \mathrm{g} / \mathrm{ml}$. The amounts of total phenolics in different fractions were calculated as $\mu \mathrm{g}$ of garlic acid equivalent (GAE)/ mg fraction.

Determination of antioxidant activity by DPPH radical scavenging assay The 1,1-diphenyl-2-picrylhydrazyl (DPPH) scavenging activity of fractions was evaluated according to the procedure reported by Karadag et al. [12]. Briefly, 0.25, 0.5, 0.75, $1.0 \mathrm{ml}$ of the fractions was diluted with distilled water to make up to 1 ml. DPPH reagent (2.4 mg of DPPH in $200 \mathrm{ml}$ methanol) was added to the diluted fractions. The fractions were assayed with methanol as control, gallic acid as antioxidant standard. Absorbance was measured at $517 \mathrm{~nm}$ after $30 \mathrm{~min}$ at room temperature. The absorbance of the control and samples were also estimated, and the $\mathrm{DPPH}$ scavenging activity was calculated in percentage according to the following formula:

$$
\text { Scavenging effect }(\%)=\frac{A C-A S}{A C} \times 100
$$

Where AC: control absorbance and AS: absorbance in presence of sample (fraction). 
The concentration required for a $50 \%$ reduction $\left(\mathrm{IC}_{50}\right)$ of DPPH radical was evaluated graphically.

Total flavonoids content determination Total flavonoid content was estimated according to the method of Park et al. [13]. Briefly, in a $10 \mathrm{ml}$ test tube, $1 \mathrm{ml}$ of sample (1 $\mathrm{mg} / \mathrm{ml}), 3.4 \mathrm{ml}$ of $30 \%$ methanol, $0.15 \mathrm{ml}$ of $\mathrm{NaNO}_{2}(0.5$ $\mathrm{M})$ and $0.15 \mathrm{ml}$ of $\mathrm{AlCl}_{3} \cdot 6 \mathrm{H}_{2} \mathrm{O}(0.3 \mathrm{M})$ were mixed. After $5 \mathrm{~min}, 1 \mathrm{ml}$ of $\mathrm{NaOH}$ was added. The solution was mixed thoroughly and the absorbance was measured against the reagent blank at $506 \mathrm{~nm}$. The total flavonoid content was determined from Quercetin standard calibration curve. The total flavonoids were expressed as $\mathrm{mg}$ of Quercetin equivalent per $\mathrm{g}$ of the fractions.

\section{Diabetes mellitus induction}

Diabetes mellitus was induced by intra-peritoneal injection of $50 \mathrm{mg} / \mathrm{kg}$ b.w. of streptozotocin (Sigma Chemicals, USA) in citrate buffer ( $\mathrm{pH} 4.5$ ) to fasted Wistar albino rats. Four days after, blood glucose concentration of induced rats above $220 \mathrm{mg} / \mathrm{dL}$ were considered diabetic, and used in the experiment. Diabetes induced and control rats were treated with the petroleum and diethyl ether fractions for 14 days.

\section{Anti-diabetic study}

After successful diabetes mellitus induction, diabetic animals were grouped into seven (7) of six (6) animals each $(n=6)$. Group 1 was given normal saline taken as a normal control, Group 2: STZ-treated rats administered 2 $\mathrm{ml} / \mathrm{kg}$ b.w of normal saline, Group 3: STZ induced rats treated with $5 \mathrm{mg} / \mathrm{kg}$ b.w of metformin (standard drug), Group 4 \& 5 were treated daily with $100 \mathrm{mg} / \mathrm{kg}$ and 200 $\mathrm{mg} / \mathrm{kg}$ respectively of petroleum ether fraction of $B$. ferruginea (PEFBF) after diabetes induction and Group 6 \&
Table 1 Gene Expression Analysis by RT-PCR

\begin{tabular}{llll}
\hline S/ & Gene & $\begin{array}{l}\text { Sequence for Forward } \\
\text { Primer }\end{array}$ & $\begin{array}{l}\text { Sequence for Reverse } \\
\text { Primer }\end{array}$ \\
\hline $\mathbf{1}$ & KIM-1 & $\begin{array}{l}\text { GGATGAGGATGGGTTCT } \\
\text { TAGG }\end{array}$ & $\begin{array}{l}\text { CCTGCTCTCTCTCCTTC } \\
\text { TTC }\end{array}$ \\
$\mathbf{2}$ & NGAL & $\begin{array}{l}\text { GACCTAGTAGCTGCTGAA } \\
\text { GCA }\end{array}$ & $\begin{array}{l}\text { GAGATGGAAGTGACGTT } \\
\text { GTAG }\end{array}$ \\
$\mathbf{3}$ & Cystatin & GCTGGTCGTGGAAA & CACTTCAGGTCTGCGA \\
& C & GGACAG & TGGAA \\
$\mathbf{4}$ & B-actin & AGACAGCCGCATCTTCTTGT & CTTGCCGTGGTAGAGTC \\
& & AT \\
\hline
\end{tabular}

7 were treated once daily with $100 \mathrm{mg} / \mathrm{kg}$ and $200 \mathrm{mg} / \mathrm{kg}$ respectively of diethyl ether fraction of $B$. ferruginea (DEFBF) after diabetes induction. All treatments were administered via oral route for 14 days. Concentration of the blood glucose was monitored and body weight checked after day 7, 11 and 14. On the fourteenth day, rats in all the groups were euthanized and blood samples were collected through ocular puncture after an overnight fast for biochemical analyses. The kidney tissues were excised from the animals for gene expression and histological study.

\section{Biochemical parameters}

Standard procedures were used for determination of urea level [14], creatinine level [15], total protein concentration [16] and albumin concentration [17] according to Randox assay kits (UK).

\section{Gene expression}

The method described by Omotuyi et al. [18] was used for the gene expression analysis with slight modification. Briefly, kidney tissue was used for neutrophil gelatinase associated lipocalin (NGAL), kidney injury molecule-1

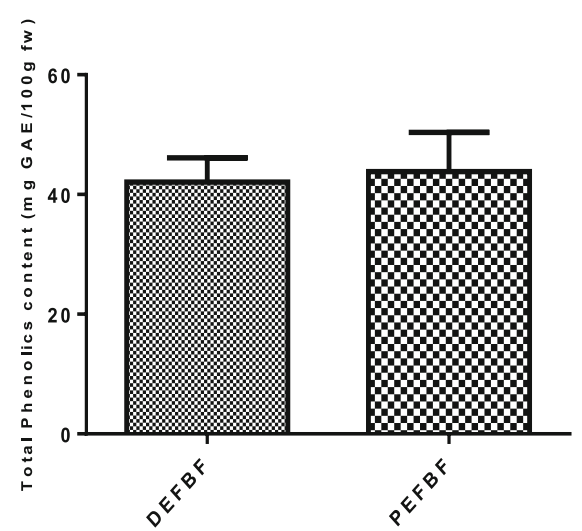

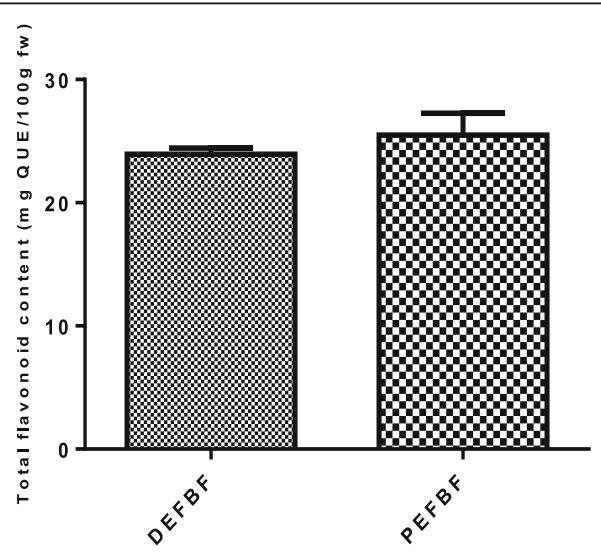

b

Fig. 1 (a-b): In vitro antioxidant capacity of petroleum and diethyl ether fractions of B. ferruginea Benth leaves: (a) Total flavonoids content (b) Total Phenolics content. PEFBF: Petroleum ether fraction of B. ferruginea; DEFBF: diethyl ether fraction of B. ferruginea 


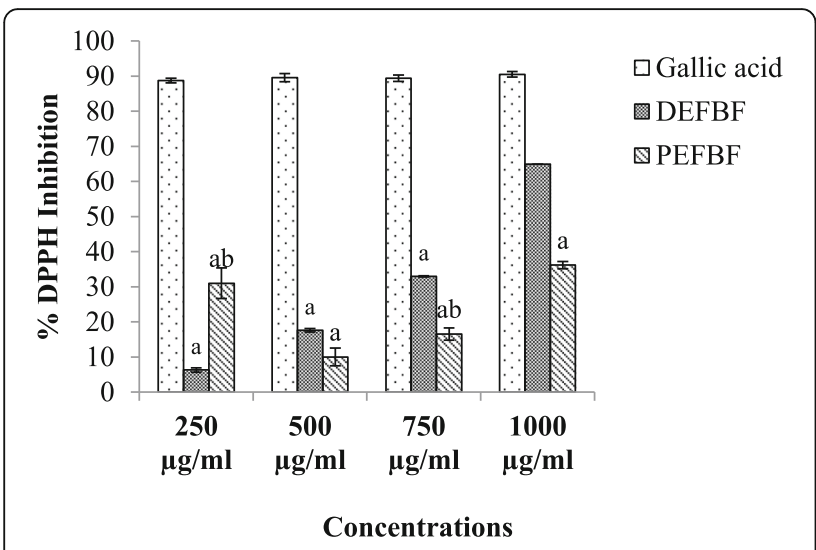

Fig. 2 DPPH scavenging activity of petroleum and diethyl ether fractions of $B$. ferruginea Benth leaves. ${ }^{a} \mathrm{P}<0.05$ : significant compared with Gallic acid; ${ }^{b} P<0.05$ : significant compared with DEFBF. DEFBF $I_{50}=426.54 \mu \mathrm{g} /$ $\mathrm{ml}$; PEFBF IC ${ }_{50}=3646.59 \mu \mathrm{g} / \mathrm{ml}$; DEFBF: Diethyl ether fraction of $B$. ferruginea; PEFBF: Petroleum ether fraction of $B$. ferruginea

(KIM-1) and cystatin c gene expression with B-actin used as the house keeping gene. The RNA from kidney tissues was isolated using TRIzol reagent (Zymo Research, USA), DNA contaminant was removed by treatment with DNAase 1 (Inqaba Biotech, Hatfeild SA) according to the manufacturer's procedure. DNA-free RNA was immediately reverse transcribed into cDNA using protoscript cDNA synthesis kit (Biolabs, UK). PCR amplification was carried out using SYBR-Green (Inqaba Biotech, Hatfeild, SA) using the primers outlined in Table 1. NGAL, KIM-1 and cystatin c representative snapshot of reverse transcription polymerase chain reaction-agarose gel electrophoresis data of $B$. ferruginea and metformin treated diabetes rats. The band density quantified by Image J was plotted.

\section{Kidney histology}

The kidney tissues were completely fixed in $10 \%$ formalin; blocks were embedded in paraffin and sections cut at $5 \mu \mathrm{m}$ and stained with haematoxylin and eosin, mounted in Canada balsami microscope at $\times 400$ magnifications [19].

\section{Statistical analysis}

Data obtained from laboratory experiment were statistically subjected to graph pad prism6. The results were expressed as mean \pm standard deviation (SD). One-way analysis of variance (ANOVA) followed by turkey test. Significance value was set at $P<0.05$. The intensities of the bands form agarose gel electrophoresis were quantified densitometrically using ImageJ software.

\section{Results}

Petroleum ether fraction of Bridelia ferruginea Benth has more flavonoid and phenolic content than Diethyl ether fraction of Bridelia ferruginea Benth as shown in Fig. 1.

Figure 2 shows the DPPH scavenging activity of petroleum and diethyl ether of $B$. ferrugnea Benth leaves, the scavenging activities of the fractions were significantly $(P<0.05)$ reduced in the fractions across the concentrations compared to the standard (gallic acid). The DPPH scavenging activity of PEFBF was significantly $(P<0.05)$ higher at $250 \mu \mathrm{g} / \mathrm{ml}$ compared to DEFBF, at concentration of 500 and $1000 \mu \mathrm{g} / \mathrm{ml}$ the DPPH scavenging activity of

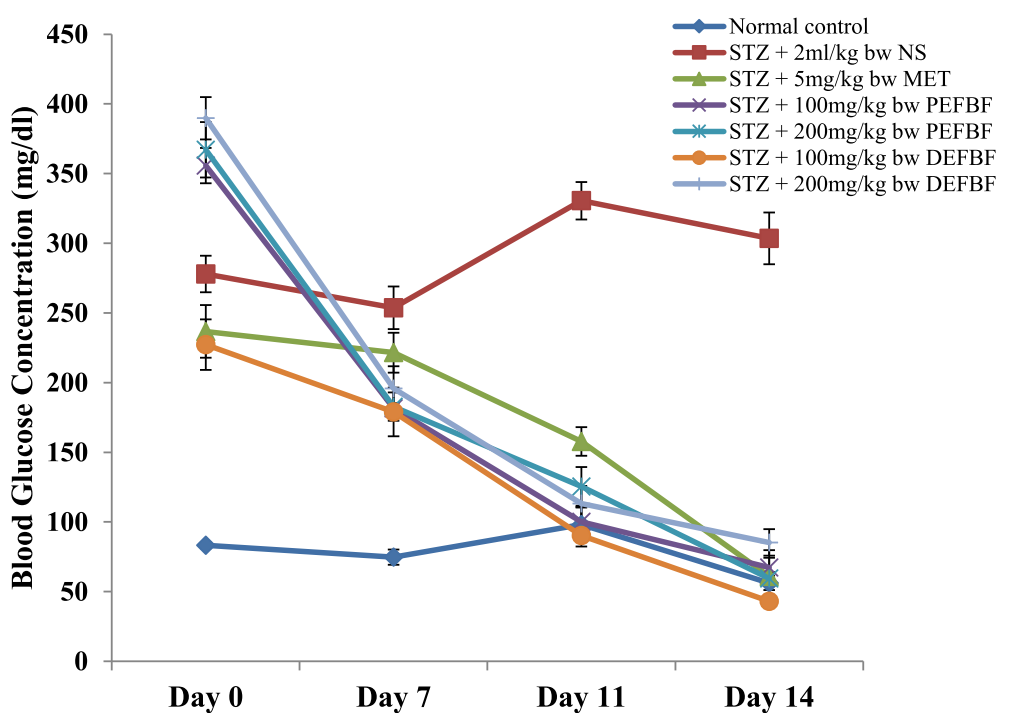

Fig. 3 Effect of petroleum and diethyl ether fractions of Bridelia ferruginea Benth on Blood Glucose Level. NS: Normal saline; MET: Metformin; PEFBF: Petroleum ether fraction of Bridelia ferruginea; DEFBF: diethyl ether fraction of Bridelia ferruginea 
PEFBF was non-significantly $(P>0.05)$ reduced compared to DEFBF while at $750 \mu \mathrm{g} / \mathrm{ml}$ the reduction was significant $(\mathrm{P}<0.05)$ as shown in Fig. 2. The $\mathrm{IC}_{50}$ of DEFBF and PEFBF were observed to be $426.54 \mu \mathrm{g} / \mathrm{ml}$ and $3646.59 \mu \mathrm{g} /$ $\mathrm{ml}$ respectively.

The STZ induced diabetes animals administered $2 \mathrm{ml} /$ $\mathrm{kg}$ b. w. of normal saline showed significantly $(P<0.05)$ higher blood glucose level on day 7,11 and 14 compared to normal control rats, also the animals induced and administrated $5 \mathrm{mg} / \mathrm{kg} \mathrm{b}$. w. of metformin showed significant $(P<0.05)$ reduction in blood glucose level on day 7 , 11 and 14 compared to animals induced and administered $2 \mathrm{ml} / \mathrm{kg}$ b. w. of normal saline. The STZ induced diabetes animals treated with 100 and $200 \mathrm{mg} / \mathrm{kb}$ b. w. of DEFBF and PEFBF showed significant $(\mathrm{P}<0.05)$ reduction in blood glucose level at day 7,11 and 14 compared to the diabetes animals administered $2 \mathrm{ml} / \mathrm{kg}$ b. w. of normal saline as shown in Fig. 3.

Figure $4 \mathrm{a}$-d showed the results of kidney function parameters of STZ induced diabetic rats treated with DEFBF and PEFBF. The STZ induced diabetic rats administered $2 \mathrm{ml} / \mathrm{kg}$ b. w. of normal saline showed significantly $(P<$ 0.05 ) higher urea, creatinine, protein and albumin concentration compared to normal control rats. The metformin

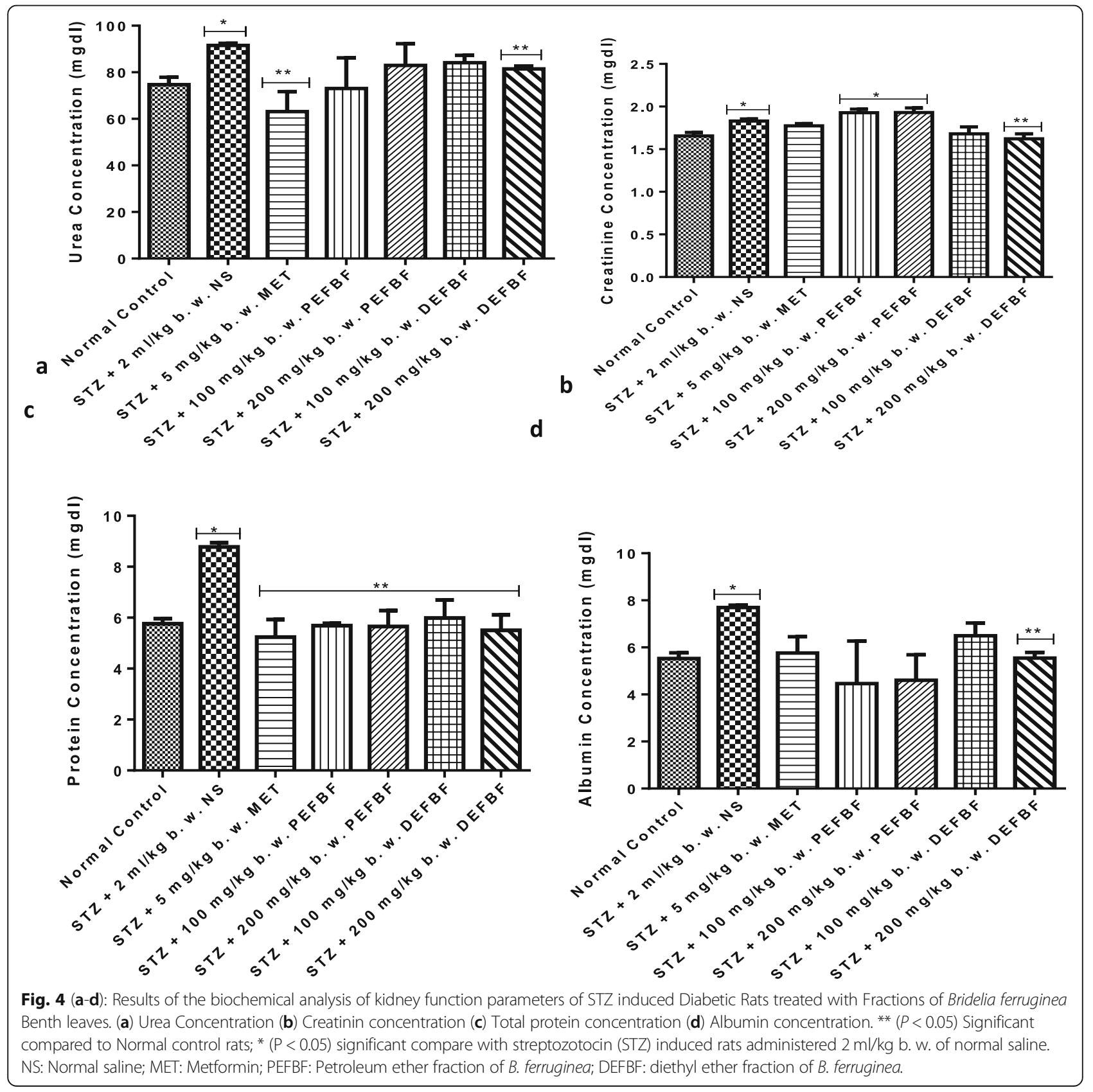



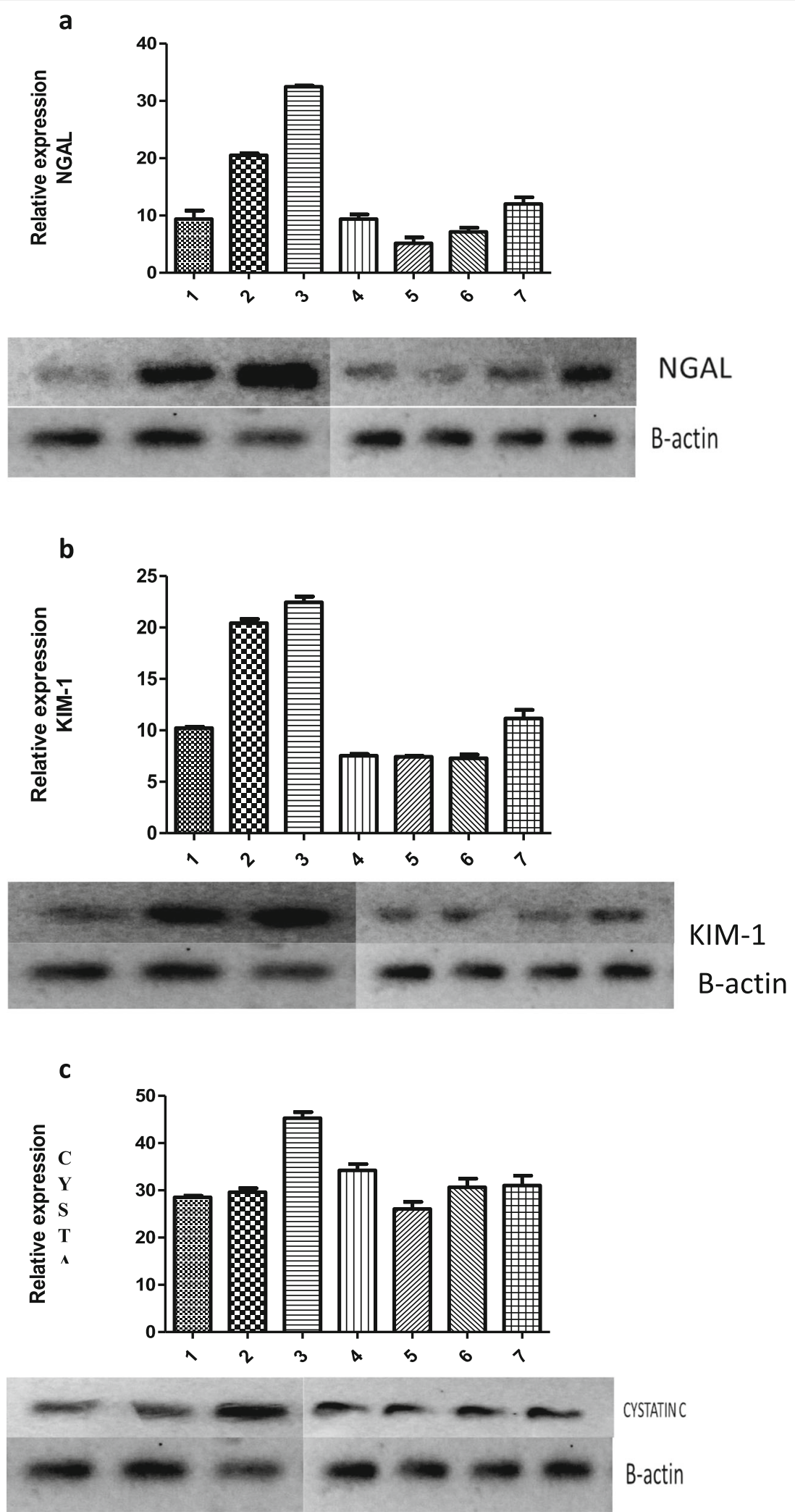

Fig. 5 (See legend on next page.) 
(See figure on previous page.)

Fig. 5 (a-c): Gene expression of kidney tissues from STZ-induced diabetes rats treated with petroleum and diethyl ether fractions of B. ferruginea Benth (a) Neutrophil gelatinase associated lipocalin (NGAL) gene expression (b) Kidney injury molecule-1 (KIM-1) gene expression (c) Cystatin C gene expression. Group 1: Normal Control animals. Group 2: STZ-induced animals administered $2 \mathrm{ml} / \mathrm{kg}$ b.w. of Normal saline. Group 3: STZinduced animals treated with $5 \mathrm{mg} / \mathrm{kg}$ b.w. of metformin. Group 4: STZ-induced animals treated with $100 \mathrm{mg} / \mathrm{kg}$ b.w. of petroleum ether fraction of B. ferruginea. Group 5: STZ-induced animals treated with $200 \mathrm{mg} / \mathrm{kg}$ b.w. of petroleum ether fraction of B. ferruginea. Group 6: STZ-induced animals treated with $100 \mathrm{mg} / \mathrm{kg}$ b.w. of Diethyl ether fraction of B. ferruginea. Group 7: STZ-induced animals treated with $200 \mathrm{mg} / \mathrm{kg}$ b.w. of Diethyl ether fraction of $B$. ferruginea

treated diabetic rats showed non-significant $(P>0.05)$ reduction in urea, creatinine, protein and albumin concentration compared to STZ induced diabetic rats administered $2 \mathrm{ml} / \mathrm{kg} \mathrm{b}$. w. of normal saline.

The STZ induced diabetic rats treated with 100 and 200 $\mathrm{mg} / \mathrm{kg}$ b.w. of PEFBF showed non-significant $(P>0.05)$ reduction in urea and albumin concentration while the protein concentration was significantly $(P<0.05)$ lowered compared to STZ induced diabetic rats administered $2 \mathrm{ml} /$ $\mathrm{kg}$ b.w. of normal saline. The diabetic rats treated with 200 $\mathrm{mg} / \mathrm{kg}$ b.w. of DEFBF showed significant $(\mathrm{P}>0.05)$ reduction in urea, creatinine, protein and albumin concentration compared to STZ induced diabetic rats administered $2 \mathrm{ml} /$ $\mathrm{kg}$ b.w. of normal saline. The urea, creatinine and albumin concentration STZ induced diabetic rats treated with 100 $\mathrm{mg} / \mathrm{kg}$ b.w. of DEFBF were observed to be non-significantly $(P<0.05)$ lowered while the protein concentration was significantly $(P<0.05)$ reduced compared to STZ induced diabetic rats administered $2 \mathrm{ml} / \mathrm{kg}$ b.w. of normal saline (Fig. 4a and c).

Figure 5a-c shows expression of neutrophil gelatinaseassociated lipocalin, cystatin $\mathrm{c}$ and kidney injury molecule-1genes in STZ induced diabetic rats administered ether fractions of $B$. ferruginea Benth leaves. The STZ induced diabetes rats administered $5 \mathrm{mg} / \mathrm{kg} \mathrm{b}$. w. of metformin shows up-regulation of the NGAL, cystatin c and KIM-1genes compared to genes of normal control animals and the STZ induced diabetes rats given $2 \mathrm{ml} / \mathrm{kg}$ b. w. of normal saline. The STZ induced diabetes rats treated with $100 \mathrm{mg} / \mathrm{kg}$ and $200 \mathrm{mg} / \mathrm{kg}$ b.w. of DEFBF and PEFBF revealed down-regulation of the NGAL and KIM-1 genes compared with the STZ induced diabetes rats given $2 \mathrm{ml} / \mathrm{kg} \mathrm{b}$. w. of normal saline and those treated with 5 $\mathrm{mg} / \mathrm{kg} \mathrm{b}$. w. of metformin. The STZ induced diabetic animals treated with $200 \mathrm{mg} / \mathrm{kg} \mathrm{b}$. w. of petroleum ether fraction of $B$. ferruginea down-regulated the NGAL and cystatin $\mathrm{c}$ genes compared with other treated animals.

Fig 6a-g shows the Photomicrographs of renal micromorphological sections of STZ-induced diabetes rats treated with petroleum and diethyl ether fractions of B. ferruginea Benth leaves. The normal control showed glomeruli with mesangial cells and capsular spaces appeared normal (white arrow), the renal tubules appear normal (blue arrow) and interstitial spaces also observed normal (slender black arrow). No observable focal sclerosis of renal glomeruli, capsular spaces around the glomerulus appears normal distinct layering. b-g Kidney of Rats histomorphological profile with different treatments (b-g) Photomicrographs of renal micromorphological sections stained by Hematoxylin and Eosin (scale bar $200 \mu \mathrm{m})$. Group B (STZ induced diabetic Rats given $2 \mathrm{ml} / \mathrm{kg}$ b.w. of Normal saline) showed poor architecture, the renal cortex showed normal glomeruli with normal mesengial cells and capsular spaces, the renal tissue is moderately hemorrhagic and there are renal tubules with epithelial degeneration and tubular necrosis, the interstitial spaces appeared mildly infiltrated (red arrows). Group C (STZ induced diabetic Rats administered $5 \mathrm{mg} / \mathrm{kg}$ b. w. of metformin)showed moderate architecture, the renal cortex shows normal glomeruli with mesengial cells and capsular spaces appeared normal, few glomeruli has wide capsular space and atrophied mesengial cells the renal tubules was observed normal, the interstitial spaces show congested vessel (red arrow). Group C (STZ induced diabetic Rats administered $100 \mathrm{mg} / \mathrm{kg}$ b. w. of PEFBF) showed poor architecture, the renal cortex shows normal glomeruli with normal mesengial cells and capsular spaces, the renal tubules appear normal, the interstitial spaces show area of severe infiltration of inflammatory cells. There is focal area of congestion and fluid accumulation seen (red arrow). Group E (STZ-induced diabetic Rats treated with $200 \mathrm{mg}$ / $\mathrm{kg} \mathrm{b}$. w. of PEFBF) shows poor architecture, the renal cortex show few glomeruli with peri-glomerular infiltration of inflammatory cells, the renal tubules degenerated epithelia cells, the interstitial spaces show moderate infiltration of inflammatory cells and no focal area of hemorrhage. Group F (STZ-induced diabetic Rats treated with $100 \mathrm{mg} / \mathrm{kg} \mathrm{b.} \mathrm{w.} \mathrm{of}$ DEFBF) showed fairly architecture, the renal cortex shows normal several normal glomeruli and few atrophied glomeruli, the renal tubules appear normal, the interstitial spaces show moderate vascular congestions. Group G (STZ-induced diabetic Rats trated with $200 \mathrm{mg} / \mathrm{kg} \mathrm{b}$. w. of DEFBF)shows moderate architecture, the renal cortex show normal glomeruli with several normal mesengial cells and capsular spaces, the renal tubules appear normal, the interstitial spaces is moderately infiltrated, signs of regenerating hepatocytes seen in clusters across the renal profile.

\section{Discussion}

Diabetic pathogenesis results in decreased renal function caused by alteration in the mesengial cell function. 


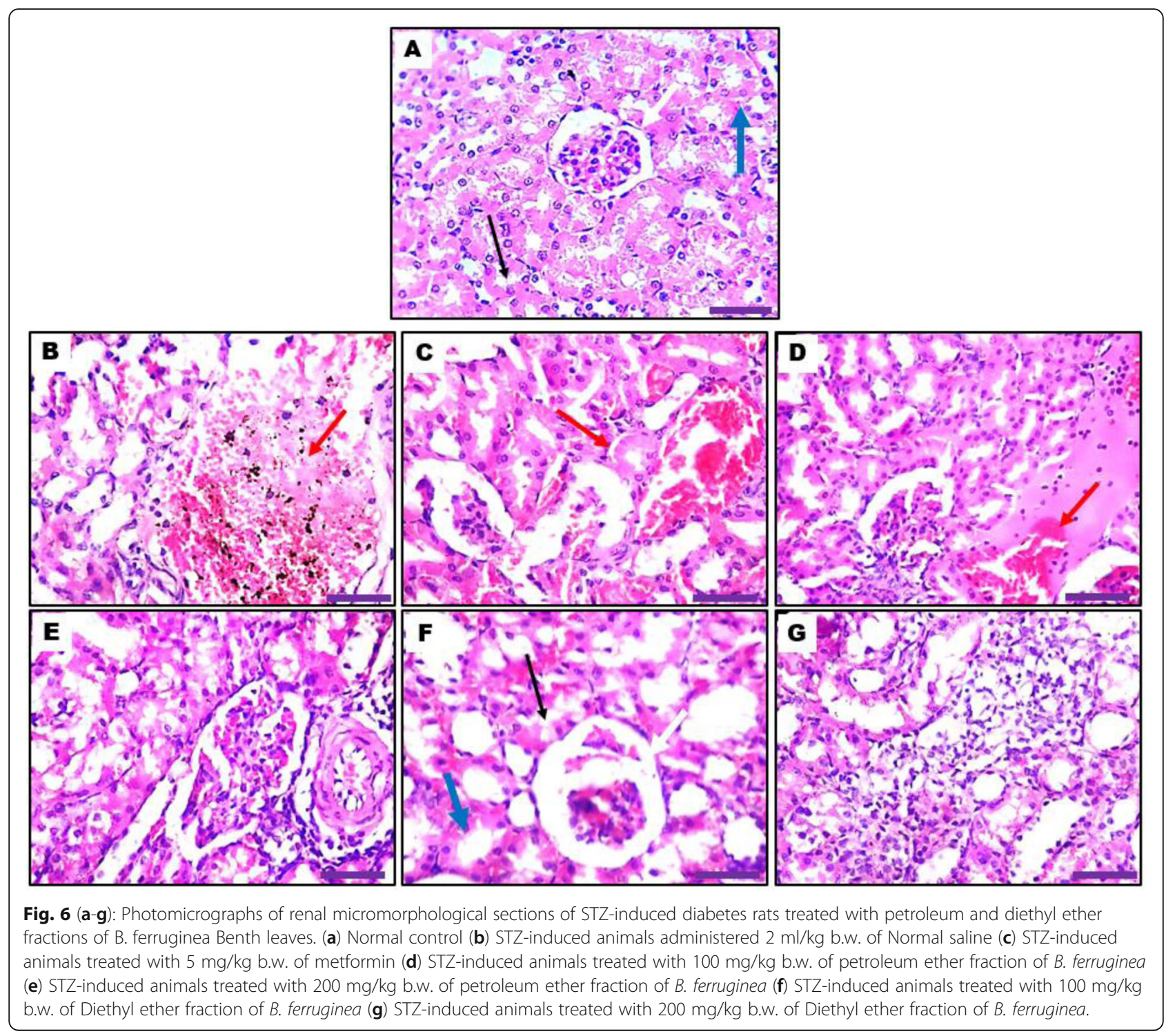

Progression of nephropathy leads to decline in glomerular filtration rate and may be due to expansion of the mesangial matrix [20]. This present study evaluated pharmacologic efficacy of ether fractions of Bridelia ferruginea Benth against diabetic complications such as diabetic nephropathy.

The increased glucose concentration in STZ-treated rats suggests hyperglycemia induction and nephropathy induction was successfully confirmed in uncontrolled diabetes with elevated urea, creatinine, albumin and protein level with up-regulation of KIM-1, NGAL and cystatin c genes. This agrees with previous reports that STZ-induced diabetic nephropathy by formation of advanced glycation end products, oxidative stress and activation of hexosamine flux causing inflammation and kidney injury [20]. However, there was significant $(P<0.05)$ reduction in the glucose level of rats treated with $\mathrm{STZ}$ and ether fractions of $B$. ferruginea Benth leaves in a dose dependent manner i.e. 100 and $200 \mathrm{mg} / \mathrm{kg}$ bw. Thus, the fractions may influence $\beta$-cells to stimulate insulin secretion. Similar results have been reported with Bridelia ndellesis ethanol extract and fractions [21].

Elevation of plasma urea, creatinine and albumin level can indicate dysfunction in glomerular filtration rate [22, 23], both urea and creatinine are major biomarkers of diabetes nephropathy [24]. In this present study, these biomarkers increased markedly in STZ-treated rats compared to normal control rats but the concentrations were lowered in STZether fractions treated rats in comparison with STZ-treated rats. This result agrees with the findings of Azarkish et al. [23] who repoted prevention of DN in STZ-induced diabetic rats after administration of Solamum nigrum fruit.

Neutrophil-gelatinase associated lipoclaim (NGAL), kidney injury molecule-1 (KIM-1) and cystatin c are 
peptides whose release into circulation is specific to tubular injury. NGAl is able to promote certain proliferative/ differentiate effects on adult kidneys [25], KIM-1 is a type 1 trans-membrane glycoprotein that is expressed on renal proximal tubule epithelial cells and is believed to play a role in renal tubule-interstitial damage [26]. Cystatin c has been reported as an endogenous low-molecular weight marker of glomerular filtration rate [25]. In this study, the expression of NGAL, KIM-1 and cystatin c genes in kidney tissues revealed up-regulation in STZ-treated rats compared to the normal control. The STZ-metformin treated group was observed to be up-regulated in these genes in comparison to STZ-treated rats but the ether fractions of $B$. ferruginea Benth leaves down regulated the genes in a dose-dependent manner.

Studies have demonstrated the relationship between oxidative stress and diabetic complications especially DN [23, 27,28 . Oxidative stress result from overload of oxidants; this impairs cellular functions and contributes to the pathogenesis of many diseases. The complications of diabetes seen to be partially mediated by generation of free radicals [29] hence, plants with anti-oxidative properties scavenge free radicals and possess antidiabetic potentials. The total flavonoids and phenolics content of $B$. ferruginea leaves were observed to be $25.49 ; 23.93 \mathrm{mgQUE} / 100 \mathrm{~g}$ and 43.81 ; $42.07 \mathrm{mgGAE} / 100 \mathrm{~g}$ for PEFBF and DEFBF respectively.

Phenolic compounds have hydroxyl groups that are prone to donate hydrogen atom to a free radical and delocalized an unpaired electrons [30]. DPPH scavenging activity of ether fractions of $B$. ferruginea was higher DEFBF at 500, 750 and $1000 \mu \mathrm{g} / \mathrm{ml}$ compared to PEFBF. The concentration of the fractions required to inhibit radical by $50 \%$ $\left(\mathrm{IC}_{50}\right)$ was observed to be 426.54 and $3646.59 \mu \mathrm{g} / \mathrm{ml}$ for DEFBF and PEFBF respectively. The lower the $\mathrm{IC}_{50}$, the more potent the fraction therefore, the diethyl ether fraction of the leaves might possess more free radical scavenging activity compared to the petroleum ether fraction. This result agrees with the findings of Olarewaju et al. [30] who reported the in-vitro anti-oxidant activities of the stem bark extract and fractions of B. ferruginea. The pathogenesis of diabetic nephropathy has also been attributed to the formation of oxidative stress [18] therefore; the therapeutic potentials of ether fractions of $B$. ferruginea Benth leaves might be attributed to its free radical scavenging activity. Further studies to isolate the anti-diabetes compound(s) suggested to be phenolic or flavonoid compounds is necessary for the purpose of drug development.

\section{Conclusion}

This present study established that, STZ-treated rats caused renal damage in rats, which was attenuated by treatment with petroleum and diethyl ether fractions of $B$. ferruginea at $100 \mathrm{mg} / \mathrm{kg}$ and $200 \mathrm{mg} / \mathrm{kg}$ b.w. PEFBF and DEFBF did not only reduce the glucose concentration of diabetes rats, they also significantly decreased renal dysfunction observed in the plasma creatinine, urea, protein and albumin levels and improved glomerular damage in DN rats. The down-regulation of NGAL, KIM-1 and cystatin c genes may have led to delay in the progression of renal failure in $\mathrm{DN}$ rats. The renal protective effect of $B$. ferruginea Benth leaf could be attributed to the antioxidant activity of the major bioactive compounds. Free radical scavenging ability and hypoglycaemic efficacy of B. ferruginea Benth makes it suitable for protection from the development or progression of diabetic nephropathy.

\section{Abbreviations \\ STZ: Streptozotocin; PEFBF: Petroleum ethter fraction of Bridelia ferruginea; DEFBF: Diethyl ethter fraction of Bridelia ferruginea; DPPH: 1,1-diphenyl-2- picryl-hydrazyl; NGAL: Neutrophil gelatinase-associated lipocalin; KIM- 1: Kidney injury molecule-1; DM: Diabetes mellitus; OSUSTECH: Ondo State University of Science and Technology}

\section{Acknowledgements}

The Authors wish to acknowledge Dr. O. O. Elekofehinti of Molecular Biology and Bioinformatics centre, Department of Biochemistry, Federal University of Technology, Akure for providing the necessary facilities to carry out the gene expression analysis. The authors received no financial support towards this work.

\section{Authors' contributions}

This work was carried out in collaboration between all authors. Authors DAO, KOK and TCA designed the study, wrote the protocol and supervised the work. Authors DAO and KOK carried out all laboratories work. Author DAO performed the statistical analysis. Authors DAO and TCA managed the analyses of the study. Authors DAO wrote the first draft of the manuscript. Authors DAO, KOK and TCA managed the literature searches and edited the manuscript. The authors read and approved the final manuscript.

\section{Funding}

Not applicable.

\section{Availability of data and materials}

The datasets generated and/or analyzed during the current study are not publicly available to protect the findings but are available from the corresponding author on reasonable request.

\section{Ethics approval and consent to participate}

The experimental protocol was approved by the Ethical Committee of Ondo State University of Science and Technology, Okitipupa, Nigeria.

Consent for publication

Not applicable.

\section{Competing interests}

The authors declare no conflict of interest.

\section{Author details}

'Department of Biochemistry, Adekunle Ajasin University, Akungba-Akoko, Ondo State, Nigeria. ${ }^{2}$ Biochemistry Program, Department of Chemical Sciences, Olusegun Agagu University of Scince and Technology, Okitipupa, Ondo State, Nigeria. ${ }^{3}$ Biotechnology Block, Bradenburg University of Technology, Cottbus-Stenftenberg Campus, Cottbus, Germany.

Received: 24 April 2020 Accepted: 6 August 2020

Published online: 04 September 2020

\section{References}

1. Thomford KP, Yeboah R, Thomford AK, Edoh DA, Mensah ML, Appiah AA. A retrospective clinical study on the effectiveness of the aqueous leaf extract of Bridelia Ferrugenia (Benth) in the management of Diabetes mellitus. Int J Herb Med. 2015a;2:20-6. 
2. Al-Trad B, Ashankyty IM, Alaraj M. Progesterone ameliorates diabetic nephropathy in streptozotocin-induced diabetic rats. Diabetol Metab Syndr. 2015;7:97-110

3. Kashihara N, Haruna Y, Kondeti VK, Kanwar YS. Oxidative stress in diabetic nephropathy. Curr Med Chem. 2010;17:4256-69.

4. Siboto A, Sibiya N, Khathi A, Ngubane P. The effects of Momordica balsamina methanolic extract on kidney function in STZ-induced diabetic rats: effects on selected metabolic markers. J Diabetes Res. 2018;18:1-8.

5. Alowanou GG, Olounlade AP, Azando EVB, Dedehou VFGN, Daga FD, Hounzangbeadote SM. A review of Bridelia ferruginea, Combretum glutinosum and Mitragina inermis plants used in zootherapeutic remedies in West Africa: historical origins, current uses and implications for conservation. J Appl Biosci. 2015;87:8003-14.

6. De-Bruyne T, Cimanga K, Pieters L, Claeys M, Dommisse R, Vlietinck A. Gallocateching allocatechin - (4_-0-7) epigallocatechin, a new biflavonoid isolated from Bridelia ferruginea. Nat Prod Lett. 1997;11:42-7.

7. Adebayo EA, Ishola OR. Phytochemical and antimicrobial screening of the crude extracts from the root, stem bark and leaves of Bridelia ferruginea. Afri J Biotech. 2009;8:650-3.

8. National Research Council. Guide for the care and use of laboratory animals. Washington D.C: National Academy Press; 1996. p. 1-79.

9. Harborne JB, Baxter H, Moss GP. Phytochemical dictionary a handbook of bioactive compounds from plants. 2nd ed; 1998. p. 86

10. Ainsworth EA, Gillespie KM. Estimation of total phenolic content and other oxidation substrates in plant tissues using folin ciocalteu reagent. Nat Protoc. 2007;2(4):875-7.

11. Karadag A, Ozcelik B, Saner S. Review of methods to determine antioxidant capacities. Food Anal Methods. 2009;2(1):41-60.

12. Park YS, Jung ST, Kang SG, Heo BK, Arancibia-Avila P, Toledo F, et al. Antioxidants and proteins in ethylene-treated kiwi fruits. Food Chem. 2008; 107(2):640-8.

13. Watt EW, Chrisp JD. Spectrophotometric method of determination of urea Anal Chem. 1954;26:452-8.

14. Peters $\mathbf{W}$. Drug resistance in malaria parasites of animals and human. Adv Parasitol. 1998;41:1-62.

15. Gornall AG, Bardawill CJ, David MM. Determination of serum proteins by means of the biuret reaction. J Biol Chem. 1949;177:751-66.

16. Doumas BT, Watson WA, Biggs HG. Albumin standards and the measurement of serum albumin with bromcresol green. Clin Chim Acta. 1971;31:87-96

17. Omotuyi Ol, Nash O, Inyang OK, Ogidigo J, Enejoh O, Okpalefe O, et al. Flavonoids-riched extract of Chromolaena odorata modulate circulatory GLP-1 in wistar rats: computational evaluation of TGR5 involvement. Biotech. 2018:8:12

18. Avwioro OG. Histochemistry and tissue pathology, principle and techniques. Nigeria: Claverianum press; 2010. p. 23.

19. Nasri H, Ardalan M, Rafieian-Kopaei M. Mechanistic impacts of medicinal plants in diabetic kidney disease. Iran J Public Health. 2014;43(9):1311-3.

20. Sokeng SD, Rokeya B, Mostafa M, Nahar N, Mosihuzzaman M, Ali L, et al. Antihyperglycemic effect of bridelia ndellensis ethanol extract and fractions in streptozotocininduced diabetic rats. Afr J Trad CAM. 2005;2(2):94-102.

21. Maharana L, Pattnaik S, Kar DM, Sahu PK, Si SC. Assessment of antihyperglycaemic and antioxidant and potential of leaves of Solanum nigrum Linn in alloxan induced diabetic rats. Pharmacologyonline. 2011;1:942-63.

22. Azarkish F, Hashemi K, Talebi A, Kamalinejad M, Soltani N, Pouladian N. Effect of the administration of Solanum nigrum fruit on prevention of diabetic nephropathy in streptozotocin-induced diabetic rats. Phcog Res. 2017;9:325-32.

23. Ahmed S, Mundhe N, Borgohain M, Chowdhury L, Kwatra M, Bolshette N. Diosmin modulates the NF-kB signal transduction pathways and downregulation of various oxidative stress markers in alloxan-induced diabetic nephropathy. Inflamm. 2016;39:1783-97.

24. Bolignano D, Donato V, Coppolino G, Campo S, Buemi A, Lacquaniti A, et al. Neutrophil gelatinase-associated Lipocalin (NGAL) as a marker of kidney damage. Am J Kidney Dis. 2008;52(3):595-605.

25. Khan FA, Fatima SS, Khan GM, Shahid S. Evaluation of kidney injury molecule-1 as a disease progression biomarker in diabetic nephropathy. Pak J Med Sci. 2019;35:992-6.

26. Bökenkamp A, Herget-Rosenthal S, Bökenkamp R. Cystatin C, kidney function and cardiovascular disease. Pediatr Nephrol. 2006;21:1223-30.
27. Parvizi MR, Parviz M, Tavangar SM, Soltani N, Kadkhodaee M, Seifi B. Protective effect of magnesium on renal function in STZ-induced diabetic rats. J Diabetes Metab Disord. 2014;13:84.

28. Omoboyowa DA, Aja OA, Vining-Ogu IC, Alum AA. Anti-hyperglycemic activity of methanol seed extract of Dioclear reflexa in alloxan-induced diabetic rats. Nig J Biochem Mol Biol. 2017;32(1):32-43.

29. Stankovic MS, Niciforovic N, Mihailovic V, Topuzovic M, Solujic S. Antioxidant activity, total phenolic content and flavonoid concentrations of different plant parts of Teucrium polium L. subsp. Acta Soc Bot Pol. 2012;81(2):117-22.

30. Olarewaju O, Oloyede O, Ojo O, Onikanni A, Ajiboye B. In-vitro antioxidant activities of the stem bark extracts fractions of Bridelia ferruginea. J Biol Agric Healthcare. 2014;4(3):1-7

\section{Publisher's Note}

Springer Nature remains neutral with regard to jurisdictional claims in published maps and institutional affiliations.

\section{Submit your manuscript to a SpringerOpen ${ }^{\circ}$ journal and benefit from:}

- Convenient online submission

- Rigorous peer review

- Open access: articles freely available online

- High visibility within the field

- Retaining the copyright to your article

Submit your next manuscript at $\boldsymbol{\nabla}$ springeropen.com 